HOW

Volume 28, Number 2, pages 33 - 52

https://doi.org/10.19183/how.28.2.604

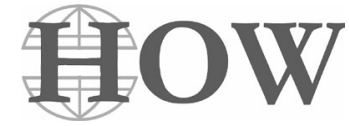

\title{
Language Pedagogy and Identity. Learning from Teachers' Narratives in the Colombian ELT
}

\author{
Pedagogía de lengua e identidad. Aprendiendo de narrativas \\ docentes en el ELT colombiano
}

\section{Diego Fernando Ubaque-Casallas ${ }^{1}$}

\begin{abstract}
This article examined two English teachers' professional identities based on a series of interviews conducted in two universities in Bogotá, Colombia. This paper examined their experiences and discourses regarding language pedagogy. Accordingly, the study adopted a narrative methodology from a decolonial lens to put some tension on the normative conception of the traditional/hegemonic notions of pedagogy and teacher identities configured in the Colombian English Language Teaching (ELT) context. Findings revealed that teachers enact their language pedagogies by merging their personal selves with their professional ones. As a result, identities and ways of knowing are validated in negotiation between doing and being. This posture towards teaching exposes their ontological and epistemic struggles for humanizing their pedagogy.
\end{abstract}

Keywords: language, narrative inquiry, pedagogy, teacher identity

\section{Resumen}

Este artículo examinó las identidades profesionales de dos profesores de inglés basándose en una serie de entrevistas realizadas en dos universidades en Bogotá, Colombia. El estudio examinó sus experiencias y discursos con respecto a su pedagogía de lengua. En consecuencia, el estudio adoptó un lente decolonial para poner cierta tensión en la concepción normativa de las nociones tradicionales / hegemónicas de pedagogía e identidad docente configuradas en el contexto de la enseñanza del idioma

He is a language teacher and teacher educator who currently works at Universidad Distrital Francisco José de Caldas, Bogotá, Colombia. He holds an MA degree in applied linguistics to the teaching of English from Universidad Distrital Francisco José de Caldas.

dfubaquec@udistrital.edu.co

ORCID ID: https://orcid.org/0000-0001-8116-9163

Received: September 7th, 2020. Accepted: March 25th, 2021.

This article is licensed under a Creative Commons Attribution-Non-Commercial-No-Derivatives 4.0 International License. License Deed can be consulted at https://creativecommons.org/licenses/by-nc-nd/4.0 
inglés (ELT). Los hallazgos revelaron que los docentes promulgan sus pedagogías de lengua fusionando su yo personal con el profesional. Como resultado, las identidades y las formas de conocimiento se validan en la negociación entre hacer y ser. Esta postura hacia la enseñanza expone sus luchas ontológicas y epistémicas para humanizar su propia pedagogía.

Palabras clave: identidad docente, lenguaje, pedagogía, investigación narrativa

\section{Introduction}

There is an upsurge in recognizing the plurality and diversity of the ways of living, being, and thinking of English teachers (e.g., Montoya-López, Mosquera-Andrade \& Peláez-Henao, 2020; Soto-Molina \& Méndez, 2020; Ubaque-Casallas \& Aguirre-Garzón, 2020; UbaqueCasallas \& Castañeda-Peña, 2020; Granados-Beltrán, 2016). Notably, the dominant ideology, epistemology, and knowledge-based methodology unquestioned for decades has started to be contested by local knowledges (Walsh, 2009) and ways of thinking and doing otherwise. In this respect, I believe that pedagogy is still a whole dimension for English language teaching (ELT), commonly understood as the approach to teaching. By extension, it has conditioned the pedagogical application of some principles merely to implement theories and practices of teaching in which conventional Western pedagogy views the teacher as a knowledge holder and the student as the recipient of that knowledge (Freire, 2008). The former evidences the dominance over language and language pedagogy in the ELT field. In fact, in the Colombian ELT context, curriculum and methodologies have dictated the formulas to guarantee a successful teaching practice (Quintero \& Guerrero, 2010). This top-down approach has turned out in a vast category, the product of standardized assumptions of teaching (Magrini, 2014) that has served to validate an academic discourse in which "the construction and imposition of terminology reinforce and instill an inferiority complex in the minds of the subaltern.” (Kumaravadivelu (2014, p. 12)

This immovable pedagogy has left aside personal theories and practices in which individuals reflect upon and experience different personal, social, political, and cultural realities. I believe there is still much complicity between those who propose the methods and theories of language teaching and we (teachers) who follow them without questioning the coercion, subjugation, and epistemic violence they abet. This assumption derives from my locus of enunciation (Grosfoguel, 2011) as a teacher educator. Departing from my own experience, I have found that some of the central ideologies of contemporary English language teaching have their origin in the constructions of colonialism. This has generated in a specific way the hegemonic construction of unique knowledge, an ideal being, and a universal way of doing that has diminished and weakened the agency's capacity, which is "a key factor to reduce inequalities" (Archanjo, Barahona \& Finardi, 2019, p. 73) among whom we educate, and by whom we are educated. 
With this assumption in mind, I think it is possible to propose a problematization of the teaching pedagogical practice and knowledge production by enabling the transformation of the discourse and relationships of inequality in the production of knowledge, in educational contexts where colonial and imperial histories (Andreotti, 2011) have been present. Hence, I directly address the ELT field, where most foundations regarding language teaching, learning, and professional identity are rooted in North/Western epistemologies (e.g., Borg, 2003; Johnson, 2006; Mitchell, 2014).

However, I do not intend to deny the fundamental significance brought forth by the implementation of methods and approaches in language teaching. Nevertheless, I aim to re-signify the epistemological, theoretical, and methodological principles to give coherence to a language pedagogy that revolves not only around the nature of the language. I intend to offer an ethical and aesthetic dimension from which the teacher gives meaning to teaching by enacting the possibilities of being and doing otherwise. Consequently, this study aims to provide a local understanding of language pedagogy in the ELT field. As such, far from opposing existing conceptions of professional identity and language pedagogy, it is interested in enriching existing knowledge regarding the subject of study. This is why data constructed by two teachers of English and reported in this manuscript intend to add a different glance towards a more diverse, local, and alternative vision of language pedagogy that continues to be permeated by a colonial legacy.

This study adopts a decolonial lens to analyze the normative conception of the traditional/hegemonic notion of language pedagogy and teacher identity configured in the ELT context. This assumption is quite essential as the study intends to transition from a critical to a decolonial epistemology/methodology in which both stories and experiences become "counter-narratives that $[. .$.$] challenge the narratives of the master, modernity,$ eurocentrism, and coloniality" (Zabala, 2016, p. 3). I also attempt to promote a "local-tolocal connection" (Veronelli, 2016, pp. 405-406) among those who are interested in finding an epistemological rupture in which "the subaltern community has to unfreeze and activate its latent agentive capacity” (Kumaravadivelu, 2016, pp. 80-81).

\section{Theoretical Considerations}

\section{Notions about Colonial Knowledge}

The coloniality of knowledge is a concept this study understands as (1) the power and the epistemic knowledge that has been Westernized (Grosfoguel, 2006) and (2) as the repression of other ways of producing knowledge separate from the white European scientific one (Walsh, 2005). Such coloniality then encapsulates the Euro-American model's dominance over English language teaching, in which language education programs have worked as 
engines of coloniality (Shahjahan \& Morgan 2015). Nonetheless, such subalternization can be explained due to the economic dominance over education models around the globe.

In Colombia, ELT's coloniality has been tailored and made evident by adopting the Common European Framework of Reference (CEFR) as the national standard. For instance, the alignment of the national exams Saber 11 and Saber Pro with the reference above, the untouched but not unquestioned instruction and training on methods in language education programs, and the Bilingualism Plans the Ministry of Colombia has been promoting as the only way for Colombian citizens to become competitive in the global market. This interest born inside the nation/state configuration has caused English language teaching worldwide to become regarded as apolitical, ahistorical, and devoid of any moral, cultural or ethical character (Pessoa \& de Urzêda Freitas, 2012).

Taking into consideration that the ELT field is ideological as it reflects the interests of individuals or groups who are often in positions of power (Canagarajah, 2008), I want to approach such coloniality of knowledge by mapping local language pedagogies to enact a decolonial option (Kumaravadivelu, 2016; Mignolo, 2011) in matters of teaching. In doing so, I consider that not only can colonial notions of pedagogical knowledge be scrutinized, but they (notions) can also make visible those who are transgressing such colonial heritage by engaging in "ways of knowing which are alternative to occidental hegemony" (Alvarado, 2015, p. 110).

\section{Pedagogy in Language Pedagogy}

Western / American ways of knowing have influenced how teachers construct their knowledge and identities. The dominant educational practices in the Colombian ELT setting are based on a monolithic, top-down discourse (Cárdenas, González, \& Álvarez, 2010) evident in both Teacher Education Programs (TEPs) and the paradigms that underpin them. As Freire and Macedo (2003) put it, such a discourse creates a culture of silence that, I believe, ends up instrumentalizing English language teaching associating indoctrination and ideological imposition over ways of knowing and doing. There have always been theoretical roots in English language teaching, in which particular emphasis on the absorption of methods and methodologies has been a trend (Kumaravadivelu, 2006). Most TEPs in Colombia, if not all, 36 instruct student-teachers in mastering theoretical and practical knowledge where language pedagogy is not the exception (Cárdenas, González, \& Álvarez, 2010).

Here, I think it is relevant then to refer to the concept of method since it has been regarded as a "colonial construct of marginality" (Kumaravadivelu, 2003, p. 541) and, as a result, has become the theoretical principle by which many teaching practices are governed. Regarding this claim, it cannot be denied that language teaching methodologies have had a considerable influence on how English is taught. In Colombia, this influence has been made 
evident in (1) the training workshops offered by international publishing houses (Cárdenas et al., 2010); (2) the extensive and insistent bilingual policies the Ministry of Education imposes (Gómez-Sará, 2017); and (3) by the best practices, usually designed by center-based experts, that supposedly guarantee excellent results. Nevertheless, these approaches have created, as I see it, an incomplete perspective over language pedagogy.

\section{According to Granados-Beltrán (2018):}

It is focused on the meeting of standards, which represent a certain level of acquisition of that skill. However, language pedagogy has an ethical goal that goes into the construction of intersubjective meanings that help us both to understand ourselves and others in the interest of better societies. (p. 175)

I echo this former notion in which language pedagogy has to go beyond the mastering of skills as "pedagogy without a modifier is an official pedagogy, at the service of the political and economic system that sustains, promotes and also drops it in favor of more "efficient" occupations" (Palermo, 2014, p. 4). I argue that language pedagogy, in the Colombian ELT field, needs to detach itself from the "educational theories, values, evidence, and justifications of what one needs to know" (Alexander, 2008, p. 47) to become a more personal response to exist in the history, context, and reality where teaching occurs. With this, I mean to advocate for a language pedagogy that not only follows theoretical principles or a set of procedures but also, and mainly, that it be an extension of the personal epistemology and ontology of the teacher of English. In pursuing this, I aim to construct a language pedagogy that can be "understood as an essential methodology within and for social, political, ontological, and epistemic struggles for liberation (Walsh, 2013, p. 29).

Although this abovementioned definition is aligned with Freire's (1972) notion of pedagogy, I would like to add other realms in which pedagogy is perceived in a broader sense:

As something given, as in handed, revealed; as in breaking through, transgressing, disrupting, displacing, inverting inherited concepts and practices, those psychic, analytic, and organizational methodologies we deploy to know what we believe we know to make different conversations and solidarities possible; as both [an] epistemic and ontological project bound to our beingness (Alexander, 2006, p. 22).

Then, to cohere with those above, I believe that in ELT, it cannot be denied that there are evidentiary colonial roots that have made language pedagogy become detached from the ethical goal Granados-Beltrán (2018) talked about. Therefore, as "knowledge is both foundational and fundamental to any attempt at imagining a future that is fundamentally different from the present" (Ndlovu, 2018, p. 95), legitimizing local knowledges and ways of knowing, being, and doing seems essential to re-signify what we understand as language pedagogy in the ELT field. 
Consequently, it seems relevant not to oppose existing theoretical and methodological principles in ELT but to enrich language pedagogy by regarding Colombian teachers of English not just as consumers of one type of knowledge but as intellectuals who can exercise their epistemological agency. Therefore, based on teachers' construction of practical and theoretical understanding of their reality as Colombian teachers of English, I would like to think of language pedagogy as a space in which knowing, doing, and becoming reflect modes of collective re-existence that might end up in the configuration of new horizons towards the decolonial.

\section{Identities in English Language Teachers}

Identity is "both contingent and relational. In other words, "who we are as humans varies according to who we are talking to, where, and for what purposes" (Vásquez, 2011, p. 539). In fact, as teacher identity is a complex but fragmented construction that involves agency, emotions, meaning systems, and the self (Beauchamp \& Thomas, 2009), the identity of a teacher enacts many practices that depart from their personal beliefs of teaching, being, and doing. This is what makes identity a more complicated term to define. Among some definitions that popped up in the literature I consulted, not only is teacher identity maintained and negotiated through language and discourse (Varghese, Morgan, Johnston, \& Johnson, 2005), but it is also a dynamic and complex process marked by internal and external factors (Bloomfield, 2010). For instance, Barkhuizen (2017) attempted to conceptualize language teacher identities (LTIs). For him:

LTIs are cognitive in that language teachers constantly strive to make sense of themselves [...] LTIs are also cognitive because they concern teachers' beliefs, theories, and philosophies about language teaching, and they relate to both content and pedagogical knowledge. LTIs are also obviously social. they are enacted, constructed, negotiated, and projected with others - language learners, teacher colleagues, administrators, and policymakers - within both local (e.g., in the classroom) and more global contexts (e.g., the language teaching profession). (p. 4)

Although these definitions have helped me understand what teacher identity might be, these could not fully account for language teacher identities in the Colombian setting. Since being a teacher is a complex activity in which any social being is unique with individual differences (Burns \& Richards, 2009), this means that language teacher identities must also depart from "the geo-political and body-political location of the subject that speaks" (Grosfoguel, 2011, p. 5).

Hence, within the Colombian research field, Castañeda-Peña (2018) highlights that "English language teaching and learning identities are more oriented towards that goal of identifying decontextualized forms of being in the field of teaching, where there is a single and monolithic idea of the language teacher and a single and fixed idea of the language 
student" (p. 18). This assumption is critical since it supports the premise that just a single type of existence has been allowed in teaching and learning English. This means that a dominant way of existing as an English teacher and, by extension, as an English learner persists (Castañeda-Peña, 2018). Then, this ontological form of colonization and subalternization of being continues to be reproduced through discourses of professional identity linked either to epistemes from the North/West (see Block, 2006; Pavlenko \& Blackledge, 2004) or to notions of recognition from terms such as English Teachers who continue to impose a notion of marginalization in the ELT field. A widespread ideology has privileged native speakers as superior in language learning and teaching (Holliday, 2005).

Paradoxically, even in praxis, LTIs have been relegated to function, from the very conception of language, as a "tool of domination, conquest, and colonization" (García, 2019 , p. 152). As a result, there is a state of unconsciousness and passivity regarding teacher identity. For this reason, this study highlights that as teachers build an understanding of who they are in their professional context, their teaching identity is relevant due to their connection with teaching and learning (Izadinia, 2013). Therefore, LTIs could be best understood if language pedagogies are mapped not just to approach the routinization of practice (Schön, 1983) but to include a moment of reflection on the position of ontological hegemony over identity and pedagogy.

\section{Methodology}

This study adopts a narrative design (Moen, Gudmundsdottir \& Flem, 2003) to approach, via narrative interviews, Lucas' and Patrick's experiences regarding language pedagogy. Since I regard narratives as "the primary scheme by which human existence is rendered meaningful" (Polkinghorne, 1988, p. 1), I cannot detach myself from a personal assumption in which I decide to focus on how Lucas and Patrick assign meaning to the stories they share with me. Consequently, I commit to using narrative research as a tool to position their and my own political, social, ethical, and epistemic project of knowledge if we consider the colonial structures, conditions of power, and epistemic impositions.

Within the methodological responsibility this study assumes, there is a commitment to break the chain of epistemic unconsciousness, which has been tied to methodological interventions in which I also recognize a colonizing genealogy (Patel, 2019); "a matter not considered by intra-European hermeneutics centered on its corresponding methodological proposals with universal scope" (Borsani, 2014, p. 162). It is for this reason that the methodological proposal set forth here looks for an alterative conversation (Ortiz-Ocaña \& Arias-López, 2019) that seeks to abandon the claim of "investigative subjectivation" (Haber, 2011 ) and instead worries about making it clear that teachers of English, as colonized subjects, are capable of managing their pedagogy. In this sense, narrative research becomes 
a tool to ensure "that the subordinate can speak" (Mendoza, 2016, p. 112). Such an alterative conversation allows me to move from a critical to a more decolonial perspective in which such a research methodology becomes my decolonial doing as a researcher.

Consequently, assuming that each conversation is a narrative in, from, and about life, I echo Stone-Mediatore (2003, p. 150), who explains that:

Telling their own stories enables them (the narrator) to claim epistemic authority as well as to counter the objectified, dehumanized representations of them circulated by others. Narratives that probe ways to articulate and situate unspoken tensions in everyday life can transform experience, helping those of us who have been reduced to victim to claim agency.

\section{Context of the Study and Participants}

Two teachers of English who work at well-known universities in Bogotá, Colombia, shared their teaching experiences in this study. Lucas and Patrick (not their real names) participated in a six-month study to collect their narratives regarding their pedagogies of teaching in the university contexts where they work. Both hold an MA in Applied Linguistics to TEFL and have more than twelve years of experience teaching English in multiple and varied educational contexts in Colombia. They were invited to converse in this study as they are active members of the local ELT community in Colombia and have provided relevant knowledge on language pedagogy. Something worth documenting in this study.

\section{Data Construction and Analysis}

As a narrative is a way of accessing knowledge (Domínguez \& Herrera, 2011), I did not look for a process of data collection. Instead, I tried to work on a data construction process from which I could access narrative knowledge. This process started with the conversations I engaged in with Lucas and Patrick. In this process, I positioned myself in what Ortiz-Ocaña and Arias López (2019) denote as Communal Contemplating. This can be understood as the intention of trying to configure a "decolonial feeling-listening-experiencing-observing, a collective listening-perceiving-observing" (p. 10), in which other knowledge can emerge since those who participate in conversation do not seek an authoritative position. In doing so, I acknowledged that my positioning was not intended to abstract information from those with whom I was conversing, but instead, I was trying to configure their and my subjectivity by engaging in an Alterative Conversation (Ortiz-Ocaña \& Arias-López, 2019) in which "the comprehensive conceptual configurations, the wisdoms - "other" knowledge - are forged" (Walsh, 2013, p. 138). In fact, as conversations with Lucas and Patrick proposed a dialogue about identities, language pedagogies, and their vestige of coloniality in which, according to Grosfoguel (2010), it is necessary to seek not the breaking of the link between the subject of the enunciation, but its positioning within "the colonial power/knowledge structures from 
which the subject speaks" (p. 459), they were not subjected to respond to a particular prompt, nor did they receive guidelines to engage in conversation. Instead, they were invited to talk about their pedagogical practices as these were striving to recover pedagogy in language as a mechanism of unlearning, learning, and relearning (Escobar-Gómez, 2019). Finally, I moved into a Configurative Reflection mode to problematize practices, knowledge, and feelings (Ortiz-Ocaña \& Arias-López, 2019), functioning as a system of meaning in the experiences shared. This became not only an ethical endeavor in which Lucas and Patrick were invited to read the subjective essence of our conversations but the thing that allowed me to disclose and reveal the intimacy of our conversations in this manuscript.

\section{Findings}

Experiences reported hereafter configure the analytical lens to understand language pedagogies after observing, feeling with, and listening to Lucas and Patrick. I consider it worth mentioning that the attempt made in the following memories/narratives was to focus on "the knower rather than on the known" (Mignolo, 2009, p. 4), and as such, the analysis below is one of listening to know what they have to say, and understanding what is said in order not to fall into an extractivist methodology limited to coding or categorizing their experiences.

\section{My Conversation with Lucas}

Lucas is a teacher of English who currently works for a private university in Bogotá, Colombia. Lucas has more than 25 years of experience and has worked in various BA programs in which he has acquired vast experience teaching diverse populations. Lucas, for the last 12 years, has been interested in working with pre-service teachers. During this time, he has been able to reconstruct his own identity as a teacher of English and has been able to position himself as a language pedagogy teacher: "I do not really see myself as an English teacher now, I see myself as a teacher of pedagogy perhaps more than an English teacher," he states. The aforementioned is quite interesting as research suggests that identity construction is a socially legitimated process where individuals interpret themselves as a particular person within a specific context (Beijaard, Meijer \& Verloop, 2004). Nonetheless, Lucas narrates his professional persona underlying the interweaving relation between his identity and his practice.

For Lucas, the main reason why he now sees himself more as a language pedagogy teacher is the fact that he builds his professional identity on four keywords. The first one:

Bueno, yo en realidad no me veo como profesor de inglés ahora, yo me veo como profesor de pedagogía tal vez. más que profesor de inglés. Pero yo creo, como que me definen cuatro palabras, en una cápsula narrativa por 
decirlo de alguna manera yo pensaría en cuatro palabras. La primera, como que creo que es la palabra y su poder transformador, yo como docente siento que, gran parte de mi profesión es por la calidad de la palabra y el uso que hago de la misma ya que yo trato de establecer relaciones más amenas con los estudiantes no solo de -yo lo sé, yo les digo- mi poder como profesor no está en lo que impongo, está en cómo me relaciono más justamente. Por eso lo que hago, como lo bago, lo que leemos, busca esto que te acabo de decir. ${ }^{2}$

Lucas seems to engage in the construction of his own professional identity based on more open relationships. Such an agency opens new possibilities to advance in reflections toward other possible ways of knowing in the ELT field that move away from English instruction's colonial histories. For example, Buchanan (2015) underlines that there is a mutual relationship between one's professional agency and professional identity:

An individual's professional agency is reciprocally related to his or her professional identity. As teachers construct an understanding of who they are within their school and professional context, they take actions that they believe align with that construction. Those actions (and how the actions are perceived by others) then [provide] feedback into the ongoing identity construction process. (p. 704)

Now, Lucas' use of the language is essential for establishing more dialogical/open relationships with students. In this respect, although Lucas acknowledges holding some power, it is more constructed than imposed (Ramos, 2004). Importantly, although colonial histories have become a critical concern within TESOL (Kumaravadivelu, 2016; Motha, 2014), power has been regarded, mainly, from a canonical disciplinary lens. However, Lucas challenges colonial ways of thinking about power and identity when choosing not to continue reproducing hegemonic teacher-student relationships within the EFL classroom. Legitimately, Lucas engages in a decolonial pedagogical bio praxis in which his thinking and doing as a teacher consider "the other" and thus avoid subalternization. According to OrtizOcaña, Arias- López, and Pedrozo- Conedo (2018), "the decolonial pedagogical bio praxis are expressed, manifested and materialized [...] in teaching, in learning and in evaluating" (p. 215). Lucas' pedagogical bio praxis mainly made evident his decision of feeling, thinking, and acting otherwise (Ortiz-Ocaña, 2017) in his teaching practice.

The second word Lucas uses to define his professional self is patience.

La segunda, que es un asunto de paciencia. Yo creo que es una habilidad que he venido trabajando a través de los años y es una paciencia entendida no sólo como el hecho de que yo tengo que saber escuchar lo que las

\footnotetext{
Well, I do not really see myself as an English teacher now. I see myself as a pedagogy teacher more than an English teacher. However, I think of four words that define who I am..., in a narrative capsule, to put it somehow, I would think of four words. The first one is word. I think it is the word and its transforming power. As a teacher, I feel that a large part of my profession is due to the quality of the words and the use I make of them since I try to establish more pleasant relationships with the students not just - I know, I tell them - My power as a teacher is not in what I impose, it is in how I relate more fairly with them. That is why what I do, how I do it, what we read, aims to achieve what I just told you.
} 
demás personas me dicen para poder interactuar efectivamente con ellos. Sin entender que los procesos de aprendizaje son de un tiempo informado y de un tiempo invertido, pues no puedo enseñar nada. Para mi eso es la paciencia para entender los tiempos y los tiempos invertidos de la gente en cualquiera de sus actividades, quienes son, lo que son ${ }^{3}$.

Patience seems to be a relevant category upon which to build his own professional identity. The fact that Lucas is aware of the importance of listening to interact with students evidences his effort "to amplify the voices, experiences, and histories of students often erased in the classroom" (Silva, 2018, p. 375), a practice of subalternization teachers may engage in when imposing power relationships in the classroom (Gutierrez, 2016), either consciously or unconsciously.

Lucas give evidence that neutrality and objectivity in teaching seem not to be an option since we always speak from a particular location within global structures (Anzaldua, 2009; Mignolo, 2007). As such, nobody escapes "the class, sexual, gender, spiritual, linguistic, geographical, and racial hierarchies of the modern/colonial capitalist/patriarchal worldsystem" (Grosfoguel, 2008, p. 2) that we seem to touch upon in the pedagogical praxis.

The third word Lucas uses is conviction.

La tercera sería como una convicción como una especie de carisma. Yo pienso que en el trabajo de la docencia es muy importante ver las cosas no siempre desde mi ángulo de aprendizaje, sino desde los ángulos de aprendizaje de los demás. Si miro solo desde lo que creo pues sería enseñarme a mí mismo. ${ }^{4}$

Lucas offers a lens to approach a language pedagogy other from the regular canon in the ELT. This epistemic/practical disobedience is what Mignolo (2009) argues as being the one way to shift the geography of reason and decolonize knowledge. For those reading this article, by epistemic disobedience, Mignolo means to de-link from the Western epistemological assumption through which the world is built. In his words:

All knowledges are situated, and every knowledge is constructed. The question is: who, when, why is constructing knowledges? Why did euro centered epistemology conceal its own geo-historical and biographical locations and succeed in creating the idea of universal knowledge as if the knowing subjects were also universal? This illusion is pervasive today in the social sciences, the

The second one is patience. Teaching is a matter of patience. I believe that it is a skill that I have been working on over the years, and patience is understood not only as the fact that I have to know how to listen to what other people tell me to be able to interact effectively with them. Without understanding that the learning processes are of an informed time and an invested time, I cannot teach anything. For me, that is the patience I talk about. Patience to understand the times and times invested by people in their activities, who they are, what they are.

The third would be conviction. It would mean a kind of charisma. I think that in teaching, it is vital to see things not always from my learning angle but others' learning angles. If I only look at what I believe, it would be like teaching myself. 
humanities, the natural sciences...epistemic disobedience means to delink from the illusion of the zero-point epistemology. (Mignolo, 2009, p.160)

Then, Lucas echoes such epistemic disobedience by being a teacher who does not conform to the disciplinary-based instruction traditionally framed by teachers' knowledge and a grand colonial narrative in which linguistic and procedural knowledge have been the central tenet (Darling-Hammond \& Lieberman, 2012). He devises ways to not only incorporate his learning perspective but to add his students'. I believe Lucas's acting evidences a way of doing otherwise and positions knowledge that distances itself from the disciplinary canon in ELT.

Walsh (2007), for example, affirms that knowledge has value, color, and a place of origin, which, in Latin America, is evident "in the maintenance of Eurocentrism as the only or at least the most hegemonic dominant perspective of knowledge" (p. 28). Remarkably, ELT keeps on neglecting or at least relegating the thinking of the localized epistemes that, as in Lucas' case, act otherwise to draw a framework for strategic plans in which student-teachers can recover their agency.

The last word Lucas uses to define his professional self is love.

Y la última, yo creo que es, yo creo que es un amor por mis estudiantes, un amor por el inglés, yo creo sobre todo a través de los años, el inglés se convirtió en una herramienta de trabajo, pero ya no lo es. Mi inglés es un asunto ya constitutivo, en la manera de mi ADN cultural entonces y como que, yo veo el inglés como una manera de extender ese amor. ${ }^{5}$

Here, although scholars such as Kaur, Yuen, and Kaur (2011) claim that an effective teacher needs to master at least two types of basic knowledge: content knowledge and pedagogical knowledge, being the former an extension of disciplinary knowledge, Lucas adds one big relevant category of personal pedagogical knowledge. For Lucas, love is embedded in his own self. As such, this category is not conceived in the North/Western canon of professional identity or pedagogy. Therefore, Lucas' envisions and enacts a more human language pedagogy in which to be human is to exist with and for others (Latini, 2009), a claim in which teaching "must involve a love of the world and of other human beings" (Shakouri \& Ogholgol, 2013).

\section{My Conversation with Patrick}

Patrick is a teacher of English who currently works for a public university in Bogotá, Colombia. Patrick has more than 20 years of experience and has worked in various BA

The last one is love. I think it is love for my students, love for English. Above all, I believe English became a working tool through the years, but it is not anymore. My English is already a constitutive issue. It is my cultural DNA. It influences how I see English as a way to extend that love. 
programs. Patrick has recently been working on opening an intercultural path for those student-teachers who wish to learn to teach the language. In our conversation, Patrick shared his experience as a teacher of English with me, arguing that he has witnessed the adoption of different methodological perspectives to educate future teachers for several years. Such perspectives have moved from an interest in applying a task-based approach to now being interested in exercising intercultural pedagogies to promote a globalized agenda in ELT.

From our conversation, Patrick evidences his frustration: "teacbing is a complex task, [...] it is at times frustrating", he states. Frustration results from the hegemonic impositions that have emerged as teaching parameters in the educational context where he has worked for the last 12 years. Certain impositions are especially evident in the implantation of pedagogical discourses.

Bueno, la mayoría de los estudiantes que tenemos en los pregrados de licenciaturas en lenguas, digámoslo así, están en los estratos dos, tres y algunos tendrán estrato cuatro. son estudiantes que vienen con ideales de aprender inglés, más no de ser profesores. Es decir, hay muy pocos que consideran eso como una opción, no lo llamaría vocación. Es complejo a la hora de insistirles en la idea de querer ser docentes o de ver la lengua no solo como eso que van a enseñar. Es decir, ellos quieren aprender y desean hablar y entonces están interesados en el lenguaje, pero en las materias de contenido, relacionadas con pedagogía, didáctica de una lengua, no lo toman en serio. ${ }^{6}$

Patrick shares that some methodological/disciplinary impositions have led him to ethical and intellectual cynicism when he ends up doing what he must. In this respect, Ubilla (2004) claims that "apparently there is only the possibility of accepting the reality as it is, even if it involves marginalization, impoverishment and exclusion" (p. 65). These ideological, methodological, and even practical impositions have distanced teaching practices from the possibility of intercultural dialogue with other types of knowledge external to such impositions.

I believe that at this point, I could refer to a conceptual reference that addresses a notion of decolonial pedagogy in Patrick's experience. It starts from criticizing some instrumental categories of teaching in which the imperial West's ideologies and epistemologies (Kumaravadivelu, 2012) are still part of the imagination of those who educate and the ones educated to become English teachers. However, when Patrick narrates to deconstruct the canonical discourse in ELT, not only does he engage in a "deliberate attempt to develop a language of critique that enables colonized peoples to understand their present situation as

Most of the students in the undergraduate degrees in languages, let us put it like this, are in strata two, three, and some will have stratum four. They are students who come with ideals of learning English but not of being teachers. There are very few who consider teaching as an option; I would not call it a vocation. It is complex when it comes to insisting on becoming teachers or seeing the language not only as what they are going to teach. They want to learn and want to speak, so they are interested in language. However, in content matters related to pedagogy, didactics of a language, they do not take it seriously. 
encircled by colonialism and its structural arrangements and cultural logics" (Zavala, 2016, p. 3), but he also reveals his epistemological positioning about language.

In conversing about his experience, Patrick commits to reclaim who he is as a teacher of English.

Desde que yo empecé a ser docente me motivó mucho el cambiar prácticas que tenian docentes conmigo. Entonces yo tuve profesores en la Universidad y uno siempre los considera buenos y malos. Cuando comencé a enseñar me di cuenta de que para ser profesor uno no tiene que ser ni bueno ni malo, sino tiene que ser lo que debe ser, que es, tratar de formar a personas. A veces recuerdo las palabras de un de un rector de un colegio donde trabajé que decia: "lo importante no es llegar, dictar su materia e irse" Dejar el contenido abi, creo que la mayoría hasta de pronto lo hacemos. Tengo una concepción de la docencia, lo importante es formar personas y a mi me interesa formar personas, $y$ en la universidad lo que les digo es "formar personas y profesionales" $y$ formar personas y profesionales son como esa concepción de que deben serpersonas integras que le aporten a la sociedad. Yo me veo como eso, como una persona que trata de aportar a la sociedad al máximo?.

Patrick's positioning is quite relevant if we want to portray pedagogies otherwise. To reach any level of pedagogy that distances itself from North/Western influences, we must first "decolonize our minds" (Phillipson, 2008, p. 39), and therefore identify hegemonic impositions of English (Macedo, 2017). As such, I believe Patrick's doing reflects this, but it also reflects his pedagogical purpose. Interestingly, I could then refer not to a functional pedagogy embedded into positivist rationality but to a more fragmentary pedagogy that emerges from a holistic logic of knowing (Ortiz \& Salcedo, 2014) in which closed, rigid, and dominant dogmatic discourses are put down through Patrick's professional agency.

To give closure to my conversation with Patrick, I must say that I understand his language pedagogy as one that configures "horizons of theorizing, thinking, doing, being, feeling, looking and listening - individually and collectively - towards the decolonial" (Walsh, 2013, p. 67). As his pedagogy confronts the monologue of modern/Western/colonial reason in ELT, there is an evident insurgency and intervention that encourages the transgression and displacement of ontological, epistemic impositions that have been present in teaching practices till now.

Since I started teaching, I was very motivated to change practices that teachers had with me. So I had professors at the university, and you always consider them good and bad. When I started teaching, I realized that to be a teacher, you do not have to be good or bad. You have to be what you should be, which is, try to train people. Sometimes I remember the words of a principal of a school where I worked who said: "the important thing is not to arrive, dictate your subject and leave." Leave the content there. I think most of us do it suddenly. I have a conception of teaching; the important thing is to educate people, and I am interested in educating people. In the university, what I tell them is "to educate people and professionals" and to educate people and professionals are like that conception that they should be people of integrity who contribute to society. I see myself as that, as a person who tries to contribute to society to the maximum. 


\section{Conclusions}

No language pedagogy is neutral. Therefore, as no "approach towards ELT is free of ideology" (Benesch 1993, p. 707), this study also poses ideological and epistemological conclusions that have to be regarded as initiators of a more profound discussion in the field. Furthermore, the conclusions presented hereafter do not intend to serve as local guidelines to decolonize language pedagogy. However, these should function as a bridge for those who, as I, are interested in investigating the establishment of a global narrative of English language supremacy and hegemony (Macedo, 2017) in Colombian ELT. Therefore, the following conclusions configure my liberatory act as a teacher-researcher (Freire, 1998).

Language pedagogy in the Colombian ELT context emphasizes the acquisition of linguistics and procedural knowledge of the language. Unquestionably, not only has this led to a "de-professionalization of language teachers who become consumers rather than producers of knowledge" (Granados-Beltrán, 2018, p. 179), but it has also provoked a universalization of pedagogy in which Colombian teachers of English have become carriers of specific political and strategic intent (not always necessarily consciously). They have served to maintain the colonial architecture of English language teaching in which pedagogy is a colonial political praxis (Madge, Raghuram, \& Noxolo, 2009). However, as narratives shared in this study hold it up, language pedagogy also implies constant care for the other. For instance, Lucas evidenced that teaching is about listening to others; it is about loving.

Language pedagogy, seen from the conversations with Patrick, challenges dominant structures of knowledge production. Although the imposition of methods and methodologies over ELT teaching has legitimized a very narrow range of knowledge, most of it instrumental, Patrick evidenced that his pedagogical practice is imbued with decolonial strategies that intend to enable his agency as a teacher of English. We learn that to achieve a closer look at how language pedagogies can become decolonial strategies, it is necessary to change the set of relations that marginalize the language teaching practice from our language and learning conceptions. Then, we must wonder what our theory of language is in order to enact our conception of language and make it evident in pedagogical activities that carry our own epistemic beliefs. It is relevant that we know how it happens in class and to what extent language and learning turn into what Mignolo' (2007) labels as a grammar of decoloniality. As a result, it could be possible or at least feasible to dismantle binaries and hegemonic practices that determine academic knowledge in the ELT field that have imprisoned our own identities as English language teachers. After all, education is a modern institution that, regardless of what our ethical stances are, can install oppression (Patel, 2019). 


\section{References}

Alexander, J. (2006). Pedagogies of crossing. Meditations on feminism, sexual politics, memory, and the sacred. Duke University Press.

Alexander, R. (2008). Essays in pedagogy. Routledge.

Alvarado, J. (2015). Pensar la educación en clave decolonial [Think decolonial education]. Revista de Filosofía, 81(3), 103-116.

Andreotti, V. (2011). Actionable postcolonial theory in education. Palgrave Macmillan US.

Anzaldua, G. (2009). The Gloria Anzaldua Reading. Duke University Press.

Archanjo, R., Barahona, M., \& Finardi, K. R. (2019). Identity of foreign language pre-service teachers to speakers of other languages: insights from Brazil and Chile. Colombian Applied Linguistics Journal, 21(1), 62-75.

Barkhuizen, G. (Ed.) (2017). Reflections on language teacher identity research. Routledge.

Beauchamp, C., \& Thomas, L. (2009). Understanding teacher identity: An overview of issues in the literature and implications for teacher education. Cambridge Journal of Education, 39(2), 175- 189 .

Beijaard, D., Meijer, P. C., \& Verloop, N. (2004). Reconsidering research on teachers' professional identity. Teaching and Teacher Education, 20(2), 107-128.

Benesch, S. (1993). ESL, ideology, and the politics of pragmatism. TESOL Quarterly 27(4), 705717.

Block, D. (2006). Multilingual identities in a global city: London stories. Palgrave.

Bloomfield, D. (2010). Emotions and "getting by": A pre-service teacher navigating professional experience. Asia-Pacific Journal of Teacher Education, 38(3), 221-234.

Borg, S. (2003). Teacher cognition in language teaching: A review of research on what language teachers think, know, believe, and do. Language Teaching, 36(2), 81-109.

Borsani, M. E. (2014). Reconstrucciones metodológicas y/o metodologías a posteriori. Astrolabio, 13, 146-168.

Buchanan, R. (2015). Teacher identity and agency in the era of accountability. Teachers and Teaching: Theory and Practice, 21(6), 700-719.

Burns, A., \& Richards, J. C. (2009). The Cambridge guide to second language teacher education. Cambridge University Press.

Canagarajah, A. S. (2008). The Politics of English Language Teaching. In S. May \& N. Hornberger (Eds.), Language Policy and Political Issues in Education: Encyclopedia of Language and Education (pp. 213-227). Springer.

Cárdenas, M. L., González, A., \& Álvarez, A. (2010). In-service English teachers’ professional development: Some conceptual considerations for Colombia. Folios, 31, 49-68.

Castañeda-Peña, H. (2018). Structuralist, poststructuralist and decolonial identity research in English language teaching and learning: A reflection problematizing the field. In H. A. Castañeda- 
Peña et al. (2018), ELT local research agendas I (pp. 17-35). Universidad Distrital Francisco José de Caldas.

Darling-Hammond, L., \& Lieberman, A. (Eds.) (2012). Teacher Education around the World: Changing Policies and Practices. Routledge.

Domínguez, E., \& Herrera, J. (2011). La investigación narrativa en Psicología: Definición y funciones. Revista Psicología desde El Caribe, 30(3), 620-641.

Escobar-Gómez, M. (2019). Decolonial responsibility within international higher education: Institutional commitment and resistance strategies. Voces y silencios. Revista Latinoamericana de Educación 10(1), 113-126.

Freire, P. (1972). Pedagogy of the Oppressed. Penguin.

Freire, P. (1998). Pedagogy of freedom: Ethics, democracy, and civic courage. Rowman \& Littlefield.

Freire, P. (2008). The "Banking" concept of education. In D. Bartholomae \& A. Petrosky, Ways of reading ( $8^{\text {th }}$ ed., pp. 242-254). Bedford St.

Freire, P., \& Macedo, D. (2003). Rethinking literacy: A dialogue. In A. Darder, M. Baltodano, \& R. Torres (Eds.), Critical pedagogy reader (pp. 354-364). Routledge Falmer.

Garcia, O. (2019). Decolonizing foreign, second, heritage, and first languages. Implications for education. In D. Macedo (Ed.), Decolonizing foreign language education. The misteaching of English and other colonial languages (pp. 152-168). Routledge.

Gómez-Sará, M. M. (2017). Review and analysis of the Colombian foreign language bilingualism policies and plans. HOW, 24(1), 139-156.

Granados-Beltrán, C. (2016). Critical interculturality. A path for pre-service ELT teachers. Íkala, $21(2), 169-185$.

Granados-Beltrán, C. (2018). Revisiting the need for critical research in undergraduate Colombian English language teaching. HOW, 25(1), 174-193.

Grosfoguel, R. (2006). From postcolonial studies to decolonial studies: Decolonizing postcolonial studies. Review: A Journal of the Fernand Braudel Center 29(2), 143-166.

Grosfoguel, R. (2008). Transmodernity, border thinking, and global coloniality. Decolonizing political economy and postcolonial studies. www.humandee.org

Grosfoguel, R. (2010). Para descolonizar os estudos de economia política e os estudos pós-coloniais: Transmodernidade, pensamento de fronteira e colonialidade global. In B. Sousa Santos \& M. Meneses (Org.), Epistemologias do sul. Cortez.

Grosfoguel, R. (2011). Decolonizing post-colonial studies and paradigms of political-economy: Transmodernity, decolonial thinking, and global coloniality. Transmodernity: Journal of Peripheral Cultural Production of the Luso-Hispanic World, 1(1), 1-38.

Gutierrez, L. (2016). Students' power relationships within an EFL classroom. Enletawa Journal, 9(1), 33-51.

Haber, A. (2011). Nometodología Payanesa: Notas de metodología indisciplinada (con comentarios de Henry Tantalean, Francisco Gil García y Dante Angelo). Revista Chilena de Antropología, (23). 
Johnson, K. E. (2006). The sociocultural turn and its challenges for second language teacher education. TESOL Quarterly, 40(1), 235-257.

Izadinia, M. (2013). A review of research on student teachers' professional identity. British Educational Research Journal, 39(4), 694-713.

Holliday, A. (2005). The struggle to teach English as an international language. Oxford University Press.

Kaur, G., Yuen, C., \& Kaur, S. (2011). Assessing ESL teacher trainees' content, pedagogical, and professional knowledge base. The assessment handbook, 4(2), 4-15.

Kumaravadivelu, B. (2003). Beyond methods: Macro strategies for language teaching. Yale University Press.

Kumaravadivelu, B. (2006). TESOL Methods: Changing tracks, challenging trends. TESOL Quarterly, 40, 59-81.

Kumaravadivelu, B. (2012). Individual identity, cultural globalization, and teaching English as an international language. In L. Alsagoff, S. L. McKay, G. Hu, \& W. A. Renandya (Eds.), Principles and practices for teaching English as an international language (pp. 9-27). Routledge.

Kumaravadivelu, B. (2014). The decolonial option in English language teaching: Can the subaltern act? TESOL Quarterly, 50(1), 66-85.

Kumaravadivelu, B. (2016). The decolonial option in English teaching: Can the subaltern act? TESOL Quarterly, 50(1), 66-85.

Latini, T. F. (2009). Nonviolent communication: A humanizing ecclesial and educational practice, JE \& CB, 13(1), 19-31.

Macedo, D. (2017). Imperialist desires in English-only language policy. The CATESOL Journal, 29(1), 81-110.

Magrini, J. (2014). Social efficiency and instrumentalism in education: Critical essays in ontology, phenomenology, and philosophical hermeneutics. Routledge.

Madge, C., Raghuram, P., \& Noxolo, P. (2009). Engaged pedagogy and responsibility: A postcolonial analysis of international students. Geoforum, 40, 34-45.

Mendoza, B. (2016). Coloniality of gender and power: From postcoloniality to decoloniality. In L. Disch \& M. Hawkesworth, The Oxford handbook of feminist theory (pp. 100-121). Oxford University Press.

Mignolo, W. (2007). Delinking: The rhetoric of modernity, the logic of coloniality, and the grammar of decoloniality. Cultural Studies, 21(2), 449-514.

Mignolo, W. (2009). Epistemic disobedience, independent thought, and decolonial freedom. Theory, Culture \& Society, 26(7-8), 159-181.

Mignolo, W. (2011). The darker side of Western modernity: Global futures, decolonial options. Duke University Press.

Mitchell, R. (2017). Language teaching research and language pedagogy. ELT Journal, 68(3), 357360 .

Moen, T., Gudmundsdottir, S., \& Flem, A. (2003). Inclusive practice: A biographical approach. Teaching and Teacher Education, 19, 359-370. 
Montoya-López, J. C., Mosquera-Andrade, A. V., \& Peláez-Henao, O. A. (2020). Inquiring preservice teachers' narratives on language policy and identity during their practicum. HOW, 27(2), 51-72.

Motha, S. (2014). Race, empire, and English language teaching: Creating responsible and ethical anti-racist practice. Teachers College Press.

Ndlovu, M. (2018). Coloniality of knowledge and the challenge of creating African futures. Ufahamu: A Journal of African Studies, 40(2).

Ortiz-Ocaña, A. (2017). Decolonizar la investigación en educación. Revista Praxis, 13(1), 93-104. http:/ /dx.doi.org/10.21676/23897856.2112

Ortiz-Ocaña, A., Arias López, M., \& Pedrozo-Conedo, Z. (2018). Hacia una pedagogía decolonial en/desde el sur global. Revista nuestra América, 6(12), 196-222.

Ortiz-Ocaña, A., \& Arias-López, M. (2019). Hacer decolonial: Desobedecer a la metodología de investigación. Hallazgos, 16(31), 147-166.

Ortiz, A., \& Salcedo, M. (2014). Pensamiento configuracional. REDIPED.

Palermo, Z. (2014). Para una pedagogía decolonial. Del Signo.

Patel, L. (2019). Decolonizing educational research. From ownership to answerability. Routledge.

Pavlenko, A., \& Blackledge, A. (2004). Negotiation of identities in multilingual contexts. Multilingual Matters.

Pessoa, R. R., \& de Urzêda Freitas, M. T. (2012). Challenges in critical language teaching. TESOL Quarterly, 46(4), 753-776.

Phillipson, R. (2008). The linguistic imperialism of neoliberal empire. Critical Inquiry in Language Studies, 5(1), 1-43.

Polkinghorne, D. E. (1988). Narrative knowing and buman sciences. State University of New York Press.

Quintero, A. \& Guerrero, H. (2010). Dimensión social de la educación de docentes de inglés: intersección entre innovación pedagógica e investigación formativa. In T. Gimenez, \& M. C. De Goés, Formação de professores de linguas na América Latina e transformação social (pp. 167-186). Pontes Editores.

Ramos, B. (2004). Power relation in the EFL class through oral interaction [Unpublished Master's dissertation]. Universidad Distrital Francisco José de Caldas.

Schön, D. (1983). The reflective practitioner. How professionals think in action. Basic Books.

Shahjahan, R., \& Morgan, C. (2015). Global competition, coloniality, and the geopolitics of knowledge in higher education. British Journal of Sociology of Education, 37(1), 92-109.

Shakouri, N., \& Ogholgol, N. (2013). Towards humanizing ELT. A Pedagogical Look. 2, 1-9.

Silva, J. M. (2018). \#WEWANTSPACE: Developing student activism through a decolonial pedagogy. American Journal of Community Psychology, 62(3/4), 374-384.

Soto-Molina, J. E., \& Méndez, P. (2020). Linguistic colonialism in the English language textbooks of multinational publishing houses. HOW, 27(1), 11-28. 
Stone-Mediatore, S. (2003). Reading across borders - Storytelling and knowledge of resistance. Palgrave Macmillan.

Ubaque-Casallas, D., \& Aguirre-Garzón, E. (2020). Re-signifying teacher epistemologies through lesson planning: A study on language student teachers. Profile: Issues in Teachers' Professional Development, 22(2), 131-144.

Ubaque-Casallas, D., \& Castañeda-Peña, H. (2020). Non-normative corporalities and transgender identity in English as a foreign language student teachers. HOW, 27(2), 13-30.

Ubilla, P. (2004). Ética y pedagogía o recreando a José Luis Rebellato. En Pedagogía de la Resistencia. Cuadernos de Educación Popular. Ediciones Madres de la Plaza de Mayo.

Varghese, M., Morgan, B., Johnston, B., \& Johnson, K. (2005). Theorizing language teacher identity: Three perspectives and beyond. Journal of Language, Identity, and Education, 4(1), 21-44.

Veronelli, G. (2016). A coalitional approach to theorizing decolonial communication. Hypatia, $31(2), 404-420$.

Vásquez, C. (2011). TESOL, Teacher identity, and the need for "Small Story" research. TESOL Quarterly, 45(3), 535-545.

Walsh, C. (2005). Interculturalidad, conocimientos y decolonialidad. Interculturality, knowledge, and decoloniality. Signo y Pensamiento,24(46), 39-50.

Walsh, C. (2007). Interculturalidad, colonialidad y educación. Revista Educación y Pedagogía, 19(48), 25-35.

Walsh, C. (2009). Interculturalidad, Estado, Sociedad. Luchas (de)coloniales de nuestra época. Abya-Yala.

Walsh, C. (2013). Introducción. Lo pedagógico y lo decolonial: Entretejiendo caminos. In C. Walsh (Ed.) (2013). Pedagogías decoloniales. Prácticas insurgentes de resistir, (re)existiry (re)vivir (pp. 23- 68) (Vol. I). Serie Pensamiento Decolonial. Abya Yala.

Zabala, M. (2016). Decolonial methodologies in education. In M.A. Peters (Ed.), Encyclopedia of Educational Philosophy and Theory. Springer Science-business Media Singapore. 